\title{
Swimming and Character Development in Early Childhood Education
}

\author{
Muchamad Arif Al Ardha ${ }^{1, *}$ Kartika Rinakit Adhe ${ }^{2}$ Chung Bing Yang ${ }^{3}$
}

\author{
${ }^{1}$ Department of Physical Education, Universitas Negeri Surabaya, Surabaya, Indonesia \\ ${ }^{2}$ Department of Early Childhood Education, Universitas Negeri Surabaya, Surabaya, Indonesia \\ ${ }^{3}$ Department of Physical Education, National Dong Hwa University, Hualien, Taiwan \\ *Corresponding author. Email: muchamadalardha@unesa.ac.id
}

\begin{abstract}
Character development in early childhood education is a crucial matter. Since children learn the value and character through their experience and the surrounding environment, character development needs to be emphasized in every teaching and learning activities. In swimming, children are motivated to be a risktaker and independent. This study aimed to inquire the effect of swimming towards character development in early childhood. It is a qualitative study which was conducted by employing a phenomenological approach. The research subjects were four swimming coaches, seven parents and nine children in Indonesia and Taiwan. The data were gathered by interviews. The study found that there are five characters in swimming i.e. discipline, honesty, independence, risk-taking and hard-working. Furthermore, these characters were formed by three steps i.e. introduction, repetition and habituation.
\end{abstract}

Keywords: Swimming, character development, early childhood education

\section{INTRODUCTION}

Swimming is a locomotion activity which must be performed in water by doing several body movements, patterns or styles (Deldicque \& Francaux, 2012). It requires a lot of energy expenditure and even higher by increasing speed (Zamparo, Cortesi, \& Gatta, 2020). The energy cost per unit distance is highly influenced by the swimming stroke and style (Capelli, Pendergast, \& Termin, 1998). For these reasons, swimming could be categorized as a high intensity sport which is ideally performed by an athlete or well-trained person (Zingg, Rüst, Rosemann, Lepers, \& Knechtle, 2014). However, the intensity could be adjusted based on various purposes, and thus, it could be performed by everyone in any age (Ratel, \& Poujade, 2009).

Swimming in early ages gives many benefits to people's physical skills and movements. It also helps them to enjoy being around and doing activities in water confidently and safely (Committee on Sports Medicine and Fitness, 2000). It could improve their physical development, coordination and range of movement. These benefits could be further advanced when students learn other sport skills (Zask et al., 2012). Many researches were conducted to inquire the association of swimming with physical benefit and health status (Gomez-Bruton et al., 2016; Font-Ribera et al., 2013; Bernard, Carbonnelle, Dumont, \& Nickmilder, 2007).
However, there is limited research that focus on the association between swimming and character development. Character is recognized as good personality, attitude, and manner. It could be defined as a comprehensive achievement of affective, cognitive and psychomotor (Marhayani, 2018). The implementation of character development in the daily activities could be started by knowing and understanding how to be a good person, willing to be a good person, and be a good person (Sudrajat, 2011). Furthermore, the research questions in this study are (1) What are the characters developed through swimming? and (2) How does swimming develop character in early childhood education?

\section{METHODS}

\subsection{Research Methods}

This is a qualitative research which was conducted by using phenomenological approach The This research was conducted in Indonesia and Taiwan. There were four swimming coaches, seven parents and nine students who were interviewed by the researchers (Table 1). The participants are chosen by the researchers in the purposive sampling technique, mainly the swimming coaches who have long experience of teaching early childhood students, parents who have early years' children, and early childhood students who are learning swimming (Table 2). 
Table 1 Research participants

\begin{tabular}{|c|c|c|c|c|}
\hline No & \multicolumn{2}{|c|}{ Research Participants } & Gender & Age \\
\hline 1. & A1 & Swimming Coach & Male & 35 \\
\hline 2. & A2 & Swimming Coach & Male & 26 \\
\hline 3. & A3 & Swimming Coach & Female & 21 \\
\hline 4. & A4 & Swimming Coach & Female & 24 \\
\hline 5. & B1 & Parent & Female & 38 \\
\hline 6. & B2 & Parent & Female & 40 \\
\hline 7. & B3 & Parent & Male & 39 \\
\hline 8. & B4 & Parent & Male & 35 \\
\hline 9. & B5 & Parent & Female & 32 \\
\hline 10. & B6 & Parent & Female & 34 \\
\hline 11. & B7 & Parent & Male & 8 \\
\hline 12. & C1 & Student & Female & 5 \\
\hline 13. & C2 & Student & Male & 6 \\
\hline 14. & C3 & Student & Male & 7 \\
\hline 15. & C4 & Student & Male & 7 \\
\hline 16. & C5 & Student & Male & 5 \\
\hline 17. & C6 & Student & Student & 5 \\
\hline 18. & C7 & Student & Student & \\
\hline 19. & C8 & & & 5 \\
\hline 20. & C9 & Male & \\
\hline
\end{tabular}

Table 2 Research participants learning groups

\begin{tabular}{|c|c|c|c|}
\hline \multirow{2}{*}{ Group } & \multicolumn{3}{|c|}{ Table Column Head } \\
\cline { 2 - 4 } & $\begin{array}{c}\text { Swimming } \\
\text { Coach }\end{array}$ & Parents & Students \\
\hline 1 & A1 & B1, B3, B4 & C1, C2, C3, C4 \\
\hline 2 & A2 & B2, B5 & C5, C6 \\
\hline 3 & A3 & B6 & C7 \\
\hline 4 & A4 & B7 & C8, C9 \\
\hline
\end{tabular}

structured interview methods to inquire of the participants swimming experience. The interview processes were

\subsection{Instrument}

The instrument in this research are 40 questions which were constructed by the researchers and applied in semi- recorded using a voice recorder by Samsung Galaxy Note 5 and picture documentation by Canon EOS 80D. 


\subsection{Procedure}

The researchers made an arrangement for interview with the participants, and then participants confirmed their availability. The interview process was approximately 30 to 60 minutes for each participant. However, some research participants were interviewed in group due to their personal preference. The swimming coaches were interviewed about their teaching experience and the interaction with the students. Furthermore, parents were asked about their children's behaviors after joining a swimming lesson. The students were asked about their feeling and experiences during learning. Finally, the research participants' explanations were transcribed and coded before the researchers reported this paper.

\section{RESULTS AND DISCUSSION}

\subsection{What are the Characters Developed through Swimming?}

Swimming does not only influence students' physical and motoric ability, but also shape the character or values developed in swimming. The data show that there are at least five characters which could possibly be developed through swimming. The characters are discipline, honesty, independence, risk-taking and hard-working. Discipline is important in the swimming pool. It includes obedience towards the swimming pool rules and the coach's instructions. When children were in the swimming pool, there were many risks which might cause serious incident if they did not follow instructions. There are several rules which must be obeyed by the students.

"Students are not allowed to run in the swimming pool areas especially if their feet are wet, because the floor becomes slippery and dangerous" - A1

"Foods are not allowed to be consumed in the swimming pool or during the swimming activity, because it may block the airways circulation" A2

"Bring your water bottle and drink often. It is important to keep the students hydrate due to the intensive swimming activity" - A2

"Playing in the swimming pool is not allowed without parents of swimming coach permission and supervision." - A3

"Warming up is a must activity, therefore coach will also lead and give the example of proper warming up to prevent the injury" - A4

"For the kids who already be able to swim, they need to accomplish the task which is given by the coach i.e. swimming in a curtain distance or a curtain time" - A1

"We will always remind them about the possibilities which may occur if they don't follow the rules. It makes them realize the important of safety in the swimming pool" - A2

"Any violation which may be done by the students will be given the consequences" - $\mathrm{A} 1$ "Cl will sleep earlier at the night before his swimming class, because he wants to perform well during the swimming lesson" - B1

"My son always remembers his swimming class schedule and make the preparation by himself" B2

"C7 always drinks water and bring her water bottle" - B6

"C9 always reminds her younger brother not to run during in the swimming pool" - B7

The second character is honesty. Honesty could be implemented inside and outside of the swimming pool. Based on the interviews result with the coaches, students are encouraged to be honest. Honesty would eventually lead them to work hard, be discipline and be the best of themselves. Parents supported what the coaches did by making honesty as habituation at home and daily routine.

"During the class, we tell them to inform us if they have finished the program" - A1

"I always tell them that the champion is the one who never give up and work hard" - A2

"I always listen the Teachers' instruction when we are on the race, Especially, in the start, I will jump if only teacher has said GO. " - C9

"My friend held my leg in the race, but I did not want to cheat" - $\mathrm{C} 4$

Independence is correlated with self-achievement and satisfaction. The coaches would generally provide the swimming lessons in accordance with an individual's capability. It is managed and evaluated regularly to ensure that every student could improve their performance. Every student is informed about his/her record and achievement, so s/he could decide the next goal. Parents would also be involved by giving the students motivation to practice harder.

"We tell the students that you are the only one who can help you to be a champion" - A1

"I always remind them to practice seriously if they want to be a winner, because winner is not a joke that everyone can easily make" - $\mathrm{A} 2$

"I want to finish the task very fast" - $\mathrm{C} 1$

"It's tiring, but I want to be fast" - C5

Risk-taking has some correlation with confidence. A coach always provides different challenges in every activity. The ability to face and conquer a challenge must be started by motivating the students about themselves. However, sometimes the challenge would also provide a reward for anyone who could accomplish it. Parents would be informed about activities which have been done by the students during the swimming lesson. It is expected they could discuss what they did during the lesson.

"Every time before we finish the lesson, I will challenge the student to make a race. Whoever win the race could have more free time to play" $-\mathrm{A} 3$ 


\begin{abstract}
"Sometimes, they are not confident to swim in the deep swimming pool. But I encourage them the beat their fear just like a small fish who swim in the ocean" - A4

"I am very happy when I win the race" - C7

"I am not afraid of swimming in the deep swimming pool, because I can swim well" - C9
\end{abstract}

Hard-working means children being persistent with their goals and doing their best to achieve it. In swimming class, coaches design the training program based on the students' capability. Every time a student passes the program, the standard and activities will be increased gradually. The increasement makes the activities become more difficult. Students might complain and refuse to do the training program. However, the coaches would persuade them to do their best and remind them about the philosophy of being a champion.

"Sometimes students are complaining about the activities, but I always tell them that it would be a problem if you are a loser" - A1

"I appreciate my student who work hard, it makes them more motivated even just by a thumb up" - A3

"I will swim as good as my coach" - C3

"I like to swim; it makes me feel like champion" $-\mathrm{C} 7$.

\subsection{How does Swimming Develop Character?}

The first step is introduction. Students are informed about the rules and expected behaviors in the swimming pool, especially if they want to be a champion. This phase requires a lot of discussion and explanation with the students in order to make them understand. Sometimes, an example or case might be given. Then the coach will lead them to analyze the reasons, and discuss about what the students think. This simple discussion will help them understand the importance of obeying the rules.

The second step is repetition. Students who have understood the rules and instruction are most likely become the majority of the group. In this phase, the coach still needs to remind them about the rules and appropriate behaviors. However, it is not necessary to repeat the explanation. Students are reminded about the key information. This action will be repeated by the students under the coach and teacher supervision. There will be less violation of the rules with the duration of the repetition time.

The last step is habituation. In this phase students will automatically obey the rules without any supervision. They will also do the behavior which they believe will support them to be a champion. The coach will be the motivator to encourage the students. With or without any violation, the coach will motivate them about the champion behavior. It could be done by telling them a successful story of a champion or even discussing a true story.

\section{ACKNOWLEDGMENT}

The research was successfully conducted by the support of Universitas Negeri Surabaya, Indonesia and National Dong Hwa University, Taiwan.

\section{REFERENCES}

Bernard, A., Carbonnelle, S., Dumont, X., \& Nickmilder, M. (2007). Infant swimming practice, pulmonary epithelium integrity, and the risk of allergic and respiratory diseases later in childhood. Pediatrics, 119(6), 1095-1103.

Capelli, C., Pendergast, D. R., \& Termin, B. (1998). Energetics of swimming at maximal speeds in humans. European Journal of Applied Physiology and Occupational Physiology, 78(5), 385-393.

Committee on Sports Medicine and Fitness. (2000). Swimming programs for infants and toddlers.

Pediatrics, 105(4), 868-870.

Deldicque, L., \& Francaux, M. (2012). Encyclopedia of exercise medicine in health and disease. Berlin: Springer Berlin Heidelberg.

Font-Ribera, L., Villanueva, C. M., Ballester, F., Santa Marina, L., Tardón, A., Espejo-Herrera, N., ... \& Sunyer, J. (2013). Swimming pool attendance, respiratory symptoms and infections in the first year of life. European Journal of Pediatrics, 172(7), 977-985.

Gomez-Bruton, A., Montero-Marin, J., GonzálezAgüero, A., Garcia-Campayo, J., Moreno, L. A., Casajus, J. A., \& Vicente-Rodriguez, G. (2016). The effect of swimming during childhood and adolescence on bone mineral density: a systematic review and metaanalysis. Sports Medicine, 46(3), 365-379.

Marhayani, D. A. (2018). Pembentukan Karakter Melalui Pembelajaran IPS. Edunomic: Jurnal Ilmiah Pendidikan Ekonomi Fakultas Keguruan dan Ilmu Pendidikan, 5(2), 67-75.

Ratel, S., \& Poujade, B. (2009). Comparative analysis of the energy cost during front crawl swimming in children and adults. European Journal of Applied Physiology, 105(4), 543-549.

Sudrajat, A. (2011). Mengapa Pendidikan Karakter?. Jurnal Pendidikan Karakter, 1(1), 47-58.

Zamparo, P., Cortesi, M., \& Gatta, G. (2020). The energy cost of swimming and its determinants. 
European Journal of Applied Physiology, 120(1), 41-

66.

Zask, A., Barnett, L. M., Rose, L., Brooks, L. O., Molyneux, M., Hughes, D., ... \& Salmon, J. (2012).

Three year follow-up of an early childhood intervention: is movement skill sustained?

International Journal of Behavioral Nutrition and Physical Activity, 9(1), 127.

Zingg, M. A., Rüst, C. A., Rosemann, T., Lepers, R., \& Knechtle, B. (2014). Analysis of swimming performance in FINA World Cup long-distance open water races. Extreme Physiology \& Medicine, 3(1), 2. 